\title{
Seizure worsening caused by low serum valproate levels from an interaction between valproate and meropenem
}

\author{
Valproat ve meropenem arasındaki etkileşime bağlı olarak serum valproat düzeyinin düşmesinin \\ ortaya çıkardı̆̆ı nöbetler
}

Suat BICÇER, Gülay ÇİLER ERDAĞ, Canan KOCAMAN YILDIRIM, Tuba GIRAY, Defne ÇÖL, Öznur KÜÇÜK, Zerrin YALVAÇ, Ayça VITTRINEL

\begin{abstract}
We present an interaction of meropenem with valproate in an epileptic child, leading to seizure exacerbations owing to the rapid lowering of serum valproate concentration. An increase of seizure frequency and somnolence were observed in the patient after the addition of meropenem to the treatment, and a rapid decline of valproate serum concentrations was observed after two doses of meropenem. This decline was the most likely cause of the increase in seizure frequency. The dosage of valproate was raised and meropenem was stopped. Two days later, the seizures stopped. Five days later, the serum valproate concentrations raised to three fold, and they rose to therapeutic levels four weeks later. To avoid drug interaction that reduces the serum concentration of valproate, meropenem in epileptic patients using valproate for the treatment of epilepsy should be administered cautiously. If concominant administration is essential, close observation of serum concentration of valproate and clinical course of the patient are necessary.
\end{abstract}

Keywords: Carbapenems, Drug interactions, Meropenem, Seizures, Valproate

Suat Biçer (凶), Gülay Çiler Erdağ, Tuba Giray, Defne Çöl, Öznur Küçük, Zerrin Yalvaç, Ayça Vitrinel

Department of Child Health and Pediatrics, School of Medicine, Yeditepe University, Istanbul, Turkey

e-mail:suat.bicer@yeditepe.edu.tr

Canan Kocaman Yıldırım

Pediatric Neurology Clinic, Erdem Private Hospital, Istanbul, Turkey

Submitted/Gönderilme: 25.01 .2015

Accepted/Kabul: 27.03.2015
ÖZET

$\mathrm{Bu}$ yazıda, meropenem ve valproat etkileşimine sekonder olarak serum valproat düzeyinin hızlı düşmesi sonucu nöbetleri alevlenen epileptik bir çocuk sunulmuştur. Hastanın tedavisine meropenem eklendikten ve iki doz kullanıldıktan sonra nöbet sıklı̆̆ı ve somnolans durumunda artış ortaya çıkan hastanın serum valproat düzeyinde ani düşme görüldü. Nöbet sıklığındaki artışın valproat serum düzeyinin düşüşüne bağlı olduğu düşünüldü. Hastanın valproat dozu artırılarak meropenem tedavisi kesildikten iki gün sonra nöbetler sona erdi. Beş gün sonra serum valproat düzeyi üç katına, dört hafta sonra ise terapötik düzeylere yükseldi. Serum valproat düzeyinin düşmesine neden olan ilaç etkileşimine neden olmamak için, valproat kullanan epileptik hastalarda meropenem dikkatle uygulanmalı, iki ilacın birlikte kullanımı mutlaka gerekliyse hastanın klinik durumu ve serum valproat düzeyi yakından izlenmelidir.

Anahtar kelimeler: İlaç etkileşimi, Karbapenemler, Meropenem, Nöbetler, Valproat

\section{Introduction}

Meropenem, is a carbapenem antibiotic, and has a broad spectrum of antimicrobial activity. Valproate is widely used in the treatment of epileptic seizures in children. In recent years, low serum concentrations of valproate were reported in children and adults receiving concomitant treatment with meropenem [1]. We present an interaction of meropenem with valproate in an epileptic child, leading to seizure exacerbations owing to the rapid lowering of serum valproate concentration.

\section{Case report}

This report describes a fourteen-year-old epileptic inpatient girl who had received concurrent treatment with meropenem for the treatment of lobar pneumonia and pleuresia, and 
valproate for the treatment of epilepsy. The patient has been epileptic since three-months of age, with motor and mental retardation, and has been diagnosed as Lennox-Gastaut syndrome. The patient was receiving valproate + lamotrigine + clobazam + levetiracetam treatment by oral route during the last three years because of resistant seizures. Serum levels of valproate were observed within the therapeutic range $(50-100 \mu \mathrm{g} / \mathrm{ml})$ during the follow-up period.

The patient was admitted to the emergency department with the complaints of cough, fever, malaise, and feeding difficulty during the last four days. She was examined as dyspneic, tachypneic, cyanotic, and dehydrated. Ceftriaxone and vancomycine were started as an initial therapy for lobar pneumonia. On the 2nd day of hospitalization, her fever and respiratory distress were relieved. On the 3rd day, serum level of valproate was $68.31 \mu \mathrm{g} / \mathrm{mL}$, within the therapeutic range (Table I). On the 4th day, the patient was clinically worse and pleuresia was diagnosed on the chest X-ray and ultrasonography. Meropenem was started on the 5th day with $1 \mathrm{gr}$ of dose twice daily intravenously, and ceftriaxone was discontinued. On the 6th day the patient became lethargic, and numerous generalised myoclonic seizure episodes occurred involving her face, arms, and legs. After two doses of meropenem, serum level of valproate, was $12.18 \mu \mathrm{g} / \mathrm{mL}$. The increase in seizure frequency and somnolence were considered to be due to the rapid decline of valproate serum concentration after addition of meropenem to the treatment. This situation was the most likely cause of increase in seizure frequency. The dosage and frequency of valproate were raised from $1000 \mathrm{mg} /$ day (500 mg, every twelve hours) to $1050 \mathrm{mg} /$ day ( $350 \mathrm{mg}$, every six hours), with nearly the same dose, and meropenem was stopped on day seven. After meropenem therapy was discontinued, piperacillin/ tazobactam was started in addition to vancomycin. Two days later, the seizures were taken under control. Five days later, the serum valproate concentration rose to three-fold and four weeks later, on day 36 , concentrations rose up to therapeutic levels (Table I). The drug interaction probability scale indicates a highly probable drug interaction between valproate and meropenem use in our patient. For this reason, the seizures were considered to be related to the concurrent administration of meropenem and valproate.

Antibiotherapy was completed on day 18, the patient recovered from pneumonia and pleurisy, and was discharged from the hospital.

\section{Discussion}

Meropenem is a carbapenem antibiotic with a broad spectrum of activity against gram-positive and gram-negative aerobic and anaerobic organisms [2]. It has been used in critically ill patients with severe infections, such as pneumonia and sepsis. The risk of seizure occurrence increases in patients using carbapenems [3]. Meropenem has a lower risk (0.02 $0.1 \%$ ) [4] of seizure than imipenem (0.4 - 0.9\%), probably due to structural differences, and their lower affinity for gamma-aminobutyric acid receptors in the central nervous system [2]. For this reason, meropenem is considered one of the best choices for patients with severe infections who have epilepsy or other neurologic diseases.

Valproate is a widely used anti-epileptic drug in the treatment of epilepsy including generalized tonic-clonic

Table 1. Valproate serum levels, valproate dose and frequency, and seizures during meropenem therapy. Valproate serum levels before, during, and after meropenem therapy. After the patient was discharged on day 18, the serum level of valproate increased up to $58.11 \mu \mathrm{g} /$ $\mathrm{mL}$ on day 36.

\begin{tabular}{|c|c|c|c|c|c|c|c|}
\hline & Day 3 & Day 5 & Day 6 & Day 7 & Day 9 & Day 17 & Day 36 \\
\hline $\begin{array}{l}\text { Valproate serum levels } \\
(\mu \mathrm{g} / \mathrm{mL})\end{array}$ & \multicolumn{4}{|l|}{68.31} & 36.7 & 39.06 & 58.11 \\
\hline $\begin{array}{l}\text { Treatment with } \\
\text { meropenem }\end{array}$ & No & $\begin{array}{c}\text { Two doses, } \\
\text { every } 12 \\
\text { hours }\end{array}$ & Discontinued & No & No & No & No \\
\hline Seizures & No & No & Yes & Yes & No & No & No \\
\hline $\begin{array}{l}\text { Dose }(\mathrm{mg}) \text { and frequency } \\
\text { of valproate }\end{array}$ & $\begin{array}{l}500 \text {, every } \\
8 \text { hours }\end{array}$ & $\begin{array}{l}500, \text { every } \\
8 \text { hours }\end{array}$ & 350 , every 8 hours & $\begin{array}{l}350, \text { every } 8 \\
\text { hours }\end{array}$ & $\begin{array}{l}350, \text { every } \\
8 \text { hours }\end{array}$ & $\begin{array}{l}350, \text { every } \\
8 \text { hours }\end{array}$ & $\begin{array}{l}350 \text {, every } \\
8 \text { hours }\end{array}$ \\
\hline
\end{tabular}


and partial seizures [2]. This drug is heavily attached to plasma proteins and largely metabolized in the liver by glucuronidation (70\%). Beta-oxidation, omega-oxidation and hydroxylation are minor pathways in the metabolization of valproate. All carbapenems, including meropenem, have lowered the serum concentration of valproate in epileptic patients to a sub-therapeutic level. Because serum valproate concentration was not decreased by carbapenems in hepatectomized rats, the liver is considered as the key organ for the decrease of valproate concentration by carbapenems. Valproate-glucuronidase in human liver microsomes, and especially in cytosol, was inhibited by carbapenems [5]. The interaction between valproate and a carbapenem (panipenem/betamipron) was first reported by Nagai et al [6] in two children in 1997. Other cases have been reported since then; as in our case, seizures have occurred during concomitant therapy of valproate and meropenem $[1,2,7,8]$.

Decline in valproate serum concentration and seizures were observed within 24 hours after concomitant administration of valproate and meropenem in our patient. The most rapid decrease of serum valproate within 24 [7] and 36 hours [6] were reported in other studies. In some other reports, this decline was observed within three to seven days after the initiation of meropenem to patients receiving valproate therapy [1]. This rapid decline in serum concentration of valproate is not explained with enzyme induction because this mechanism usually requires several days [9]. Inhibition of plasma protein binding of valproate by carbapenems has been suggested for the interaction between valproate and carbapenems [5,7]. Valproate has a high protein-binding ratio (90 - 95\%), whereas, meropenem is a low (2\%) protein bound drug. For this reason, these rapid declines may not be explained by the mechanism of competition in protein binding [10]. The most comprehensive research study on this topic was undertaken by Yokogawa et al [10]. They studied the effects of meropenem on valproate metabolism in rabbits, because metabolism of this drug is similar to that in humans. This study indicated that urinary excretion of valproate-glucuronide, and suppression of valproate-glucuronide hydrolysis in the liver were increased at the time of concomitant administration of valproate and meropenem [10]. Furthermore, suppression of valproateglucuronide hydrolysis in the gastrointestinal tract was also increased in this concomitance [10]. The mechanisms of rapid decline of valproate serum concentration has been elucidated by recent studies. Some studies have indicated that the clearance of valproate is increased by meropenem by increasing the urinary excretion of valproate glucuronide $[7,8,10]$. Other mechanisms in which decreases occur in the serum levels of valproate by carbapenems are: inhibition of the hydrolysis of valproate glucuronide, increase in the glucuronidation of valproate, suppression of enterohepatic recirculation of valproate, and increase in the erytrocyte distribution of valproate, which induce the decrease in serum levels of valproate [11]. The reduced blood levels of valproate at a fairly short time period in our patient may be caused by decreased hydrolysis of valproate-glucuronide conjugation resulting from eliminating of microorganism with beta-glucuronidase activity owing to antibacterial drugs. For these reasons, reabsorption of free valproate decreases.

Carbapenems may induce seizures during acute neurologic diseases as intracranial infections, hemorrhage, stroke, trauma, and tumors [3,9]. None of these have occurred in our patient during concomitant therapy of valproate and meropenem.

In the reported cases to date, none of the antibiotics (i.e. ceftazidime, cefotaxime, amikacin, vancomycin, ampicillin, tobramycin, and clindamycin) other than carbapenems have caused a decline of the serum concentration of valproate. In addition, serum valproate concentrations increased after the termination of carbapenems according to these reports [1]. Rapidly changed serum concentrations of valproate is not consistent with the induction of enzymes participated in valproate metabolism process.

Serum valproate concentration was decreased while under meropenem treatment and gradually returned to normal levels after cessation of meropenem in a reported 14-year old girl with cystic fibrosis and multidrug resistant pulmonary infection with intravenous antibiotics [12]. Her serum valproate concentration kept low despite elevated daily dosing of valproate and a loading dose. Finally, on the 18th day of cessation of meropenem the blood valproate level reached its normal value. The daily doses were increased, however, the loading dose was not used in our case. The low blood levels of valproate until the 36th day may be related with inadequate dose of valproate without the loading dose. Conversely, seizures were controlled after two days and the serum valproate concentration rose to threefold after the discontinuation of meropenem and increased daily valproate doses. Therefore, the loading valproate dose with increased daily doses may be used to increase the blood valproate levels.

Clinicians should be aware of the interaction between valproate and carbapenems and of the possible clinical consequences like increasing the frequency of epileptic seizures and/or status epilepticus. To avoid drug interaction that reduces the serum concentration of valproate, care should be taken when administering meropenem in epileptic 
patients using valproate for the treatment of epilepsy. If possible, another antibiotic, except carbapenems, should be used in patients using valproate or the antiepileptic therapy should be switched to another drug other than valproate. However, this second option may not be feasible in many patients if their seizures are controlled only with valproate. In addition, if the antiepileptic drug regime has changed, at least two - four weeks will be required for sufficient levels of the new antiepileptic drug to be attained [1]. If concomitant administration is essential, close observation of serum concentration of valproate and clinical course of patient are necessary.

There were not plasma levels of other antiepileptic drugs excluding valproate.

\section{Acknowledgement}

We are grateful to Cahit Zereycan (writing consultant of Writing Center at Yeditepe University) for the revision of this paper in English.

\section{Financial disclosure: None}

Funding: This study was not funded.

Author contributions: Suat Biçer developed the idea of the case report. He abstracted analysed, prepared, wrote and drafted it. Gülay Çiler Erdağ, Canan Kocaman, Tuba Giray, Defne Çöl, Öznur Küçük, Zerrin Yalvaç, and Ayça Vitrinel contributed the case report. Ayça Vitrinel and Canan Kocaman revised the case report for important intellectual content. Ayça Vitrinel revised it for English.

\section{References}

1. Nacarkucuk E, Saglam H, Okan M. Meropenem decreases serum level of valproic acid. Pediatr Neurol 2004; 31: 232-4. http://dx.doi.org/10.1016/j.pediatrneurol.2004.03.014

2. De Turck BJ, Diltoer MW, Cornelis PJ, et al. Lowering of plasma valproic acid concentrations during concomitant therapy with meropenem and amikacin. J Antimicrob Chemother 1998; 42: 563-4. http://dx.doi.org/10.1093/ jac/42.4.563

3. Calandra G, Lydick E, Carrigan J, Weiss L, Guess H. Factors predisposing to seizures in seriously ill infected patients receiving antibiotics: Experience with imipenem/cilastatin. Am J Med 1988; 84: 911-8.

4. Cunha BA. Meropenem in elderly and renally inpaired patients (corrected and republished in Int J Antimicrob Agents 1999; 11: 167-77). Int J Antimicrob Agents 1998; 10: 107-17. http:// dx.doi.org/10.1016/S0924-8579(98)00031-4

5. Nakamura Y, Nakahira K, Mizutani T. Decreased valproate level caused by VPA-glucuronidase inhibition by carbapenem antibiotics. Drug Metab Lett 2008; 2: 280-5. http://dx.doi. org/10.2174/187231208786734049

6. Nagai K, Shimizu T, Togo A, et al. Decrease in serum levels of valproic acid during treatment with a new carbapenem, panipenem/betamipron. J Antimicrob Chemother 1997; 39: 295-6. http://dx.doi.org/10.1093/jac/39.2.295

7. Spriet I, Meersseman W, De Troy E, Wilmer A, Casteels M, Willems L. Meropenem-valproic acid interaction in patients with cefepime-associated status epilepticus. Am J Health Syst Pharm 2007; 64: 54-8. http://dx.doi.org/10.2146/ajhp050512

8. Yoon H, Kim DH. Unusual drug reaction between valproate sodium and meropenem. Int J Clin Pharm 2013; 35: 316-8. http://dx.doi: 10.1007/s11096-013-9763-2.

9. Mann HI. Drug-associated disease: Cytochrome P450 interactions. Crit Care Clin 2006; 22: 329-45. http://dx.doi. org/10.1016/j.ccc.2006.02.004

10. Yokogawa K, Iwashita S, Kubota A, et al. Effect of meropenem on disposition kinetics of valproate and its metabolites in rabbits. Pharm Res 2001; 18: 1320-6.

11. Ogawa K, Yumoto R, Hamada N, Nagai J, Takano M. Interaction of valproic acid and carbapenem antibiotics with multidrug resistance-associated proteins in rat erythrocyte membranes. Epilepsy Res 2006; 71: 76-87. http://dx.doi. org/10.1016/j.eplepsyres.2006.05.016

12. Taha FA, Hammond DN, Sheth RD. Seizures from valproatecarbapenem interaction. Pediatric Neurology 2013; 49: 27981 . 